\title{
Swine influenza virus strains that induce interferon $\beta$ in SJPL cells but are insensitive to exogenous recombinant swine interferon $\beta$
}

Krisna N.A. Pangesti ${ }^{1}$, Marvin J. Grubman ${ }^{2}$ and Antonio E. Garmendia ${ }^{3 *}$

*Correspondence: Antonio.Garmendia@Uconn.edu

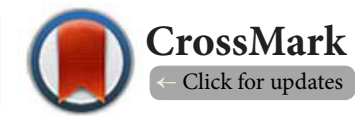

'Virology Laboratory, National Institute for Research and Development, Ministry of Health, Indonesia.

2Plum Island Animal Disease Center, USDA, Agricultural Research Service, North Atlantic Area, Greenport, New York 11944, USA.

${ }^{3}$ Pathobiology and Veterinary Science Department, University of Connecticut, Storrs, USA.

\begin{abstract}
Background: Viral infections induce expression of type I interferons (IFNa/ $\beta$ ) which result in an antiviral state within cells or animals. However, some viruses, notably influenza viruses (IV), have evolved mechanisms of evasion and blocking of IFN to survive in nature. Swine influenza virus (SIV) can inhibit IFN and as with other IV does it through its NS1 protein, identified as a virulence factor in pigs.

Methods: To determine whether different SIV strains varied in their ability to induce IFN $\beta$ in cell culture and the relative sensitivity of these strains to exogenous IFN $\beta$, three strains were tested in SJPL cells originally deposited as epithelial-like cell line of swine lung origin (ATCC, Richmond, MD) but later characterized as cells of monkey origin.

Results: The SIV strains tested here induced significant synthesis of IFN $\beta$ in SJPL cells, with levels that were higher to those induced by poly I:C. The induction of IFN $\beta$ by SIV peaked at three days post-infection and was not dependent on the infectious virus dose. Interestingly, priming the cells with exogenous recombinant swine IFN $\beta$ had no significant inhibitory effect on the replication of these SIV strains. NS1antagonistic compounds did not change IFN $\beta$ induction and had variable and unexpected effects on virus replication of the three SIV strains tested.
\end{abstract}

Conclusions: Our study showed that while the SIV strains tested here were capable to induce IFN $\beta$ in SJPL cells these were relatively resistant to the antiviral effects of exogenous IFN $\beta$. NS1-antagonistic compounds did not affect IFN $\beta$ induction and had variable effects on the replication of the SIV strains tested. These seemingly contradicting results suggest virus evasion by mechanisms other than NS1.

Keywords: Swine influenza virus, interferon $\beta$, SJPL cells, NS1 protein

\section{Introduction}

Influenza, a respiratory disease affecting humans and many mammals and birds, is caused by Influenza viruses (IV). Influenza viruses are enveloped, negative-sense, single-stranded, segmented RNA viruses of the family Orthomyxoviridae [1,2]. In humans, Influenza virus has been responsible for several pandemics that resulted in high mortality in 1918 (A/H1N1), 1957(A/H2N2), 1968 (A/H3N2) and 1977 (A/H1N1) [3]. The emergence of a new highly pathogenic avian influenza (HPAl), strain, A/H5N1, in 1997 in Hong Kong increased the awareness of the possibility of future Influenza pandemics. However, the most recent influenza pandemic was not caused by the HPAI
(H5N1), but by a new influenza strain known as A/H1N1-SOIV (swine-origin influenza virus) which emerged in Mexico in 2009 [4,5]. In 2013, avian to human transmission of a new H7N9 resulting in fatalities was recorded in China [6].

Pigs are thought to have an important role in the epidemiology of influenza. Pig respiratory epithelial cells have receptors for both human as well as avian influenza viruses $[\mathbf{9 , 1 0 ]}$. There is evidence that both humans and avian species can transmit influenza virus to pigs [11-13]. Thus, pigs are considered "mixing vessels" that facilitate re-assortment $[7,8]$ from which new influenza strains responsible for pandemics may arise. Secondly, influenza type strains cause swine influenza, a constituent of 
Pangesti et al. Virology Discovery 2014,

the porcine respiratory disease complex. Swine influenza has a high morbidity rate in pigs, although the mortality rate may be low [14]. Thirdly, swine influenza viruses (SIV)s can cause disease in humans, especially in those who have close contact with sick pigs $[9,15]$.

The innate immune response, as first line of host defense against viral infection involves the induction of type I interferons (IFNa/ $\beta$ ) and pro-inflammatory cytokines, which prevent the rapid replication and spread of viruses [16]. In addition to antiviral functions, type I IFNs has an important role in bridging innate and adaptive immunity [17]. While most viruses including influenza can induce the synthesis of type I IFN both in cell culture and in animals [18-21], the rate of induction may vary between strains and the type of host cells or animal species employed [22]. Besides viruses, many natural and synthetic molecules such as synthetic double stranded polyribonucleotide (poly I:C) can also induce IFN expression [23].

The induction of type I IFN by human influenza viruses [24-26] and several animal viruses including swine influenza virus (SIV) in cell culture and in pigs has been reported [27-29] Recently, induction of both IFNa and Mx protein in lungs of pigs experimentally inoculated with a strain of SIV has been demonstrated [30]. The production of Mx protein was speculated to be induced by IFNa. Mx1 protein is involved in protection of swine from SIV as shown by the increased susceptibility to SIV in swine with deletions in their Mx1 genes [31]. Mx may control SIV by blocking endocytic trafficking of the virus [32]. It has also been reported that the presence of pro- inflammatory cytokines including type I IFNs, TNFa, IL6 in the lungs of pigs inoculated with SIV correlates with severity of disease [28,33-35], There is also evidence that viruses have also evolved mechanisms to subvert innate immunity IFN [42] and NS1 was identified in influenza viruses as one of the viral proteins responsible for such 93 effects $[19,41,44,45]$. The experimental use of NS-1 antagonists resulted in rescue of 94 IFN induction in influenza virus infected cells confirming NS1 inhibitory role [38].

Given the crucial role of type I IFN in innate antiviral immunity and in activation of adaptive immunity, it is important to determine the effects on IFN $\beta$ synthesis in the context of influenza virus infection. This study was undertaken to determine whether different SIV strains varied in their ability to induce or suppress IFN $\beta$ in cell culture and examine the relative sensitivity of these strains to exogenous IFN $\beta$.

\section{Materials and methods \\ Cells}

SJPL cells (ATCC, Richmond, MD), originally reported as epithelial-like cell line of swine lung origin were used in the study which was completed before the publication characterizing SJPL cells as of monkey origin [36]. The cells were grown in DMEM medium supplemented with $10 \%$ fetal bovine serum (FBS), $1 \%$ sodium pyruvate, $2 \mathrm{mM} \mathrm{L-glutamine,} 10 \mathrm{mM}$ non-essential amino acids, $2.5 \mu \mathrm{g} / \mathrm{ml}$ fungizone, $100 \mathrm{U} / \mathrm{ml}$ 108 penicillin and $100 \mu \mathrm{g} / \mathrm{ml}$ streptomycin. SJPL cells were incubated in a humidified incubator with $5 \% \mathrm{CO}_{2}$ at $37^{\circ} \mathrm{C}$. All cell culture procedures were performed in a sterile class II Biosafety cabinet.

\section{Virus strains and virus titration}

Three strains of SIV, A/Sw/lowa/73 (H1N1), A/Sw/NC/18893/01 (rH1N1), and A/Sw/Tx/4199/98 (H3N2), obtained from the National Veterinary Services Laboratory (Ames, lowa) were evaluated. The viruses were propagated in 11 day-old embryonated chicken eggs by inoculation in the allantoic cavity. Allantoic fluids were harvested 3-4 days after infection. Virus growth was monitored by the hemagglutination test Identification of the viruses was performed using hemagglutination inhibition tests. The viruses were then aliquoted and stored at $-80^{\circ} \mathrm{C}$ until used.

Infectious virus particles were enumerated by conventional plaque assays in SJPL cells. Briefly, SJPL cells were seeded in 6-well plates, maintenance medium was removed and the cells were rinsed twice with serum-free media. Test viruses were diluted in serum-free media containing $1 \mu \mathrm{g} / \mathrm{ml} \mathrm{TPCK}$ trypsin and incubated in cell monolayers for $1 \mathrm{~h}$ at $37^{\circ} \mathrm{C}$ in a $5 \% \mathrm{CO}_{2}$ atmosphere. The inoculum was removed and cells were overlaid with agarose mixed with DMEM supplemented with 2x:penicillin-streptomycin, fungizone, L-glutamine, glucose, non-essential amino acids, sodium pyruvate and $2 x$ TPCK-trypsin. The plates were incubated at $37^{\circ} \mathrm{C}$, in a $5 \% \mathrm{CO}_{2}$ atmosphere. The cells were fixed with $95 \%$ cold methanol for $20 \mathrm{~min}$ and plaques stained with crystal violet.

\section{Induction of IFN $\beta$ in cell culture}

SJPL cells seeded in 24-well plates were inoculated with each SIV strain (MOI 0.005) and incubated for $1 \mathrm{~h}$ at $37^{\circ} \mathrm{C}$ in a $5 \% \mathrm{CO}_{2}$ atmosphere in serum-free DMEM containing $1 \mu \mathrm{g} /$ $\mathrm{ml} \mathrm{TPCK}$-trypsin. The inoculum was removed, the cells were washed, and serum- free medium was added. The infected cells were incubated up to $72 \mathrm{~h}$ at $37^{\circ} \mathrm{C}$, in a humidified $5 \%$ $\mathrm{CO}_{2}$ atmosphere. Culture fluids were collected at $0,24,48,72$ $\mathrm{h}$ post- infection and were acid-treated for $24 \mathrm{~h}$ and neutralized to $\mathrm{pH}$ 7.2. IFN $\beta$ was measured by an indirect ELISA test as described below.

\section{IFN $\beta$ ELISA}

An ELISA to detect IFN $\beta$ in culture fluids was developed. Briefly, culture fluids from infected or control cells acidified to $\mathrm{pH} 2.5$ and 18 hours later neutralized back to $\mathrm{pH} 7.2$ were diluted in carbonate-bicarbonate buffer $\mathrm{pH} 9.6$ and coated onto 96-well ELISA plates $\left(\operatorname{Immulon}{ }^{\circledR}\right.$ ) overnight at $4^{\circ} \mathrm{C}$. The next day, plates were washed once with wash buffer, PBS containing $0.05 \%$ Tween-20 (PBS-T), and blocked for $3 \mathrm{~h}$ at room temperature (RT) with 5\% skim milk made in PBS-Tween-20 (PBS-T). After 5 washes, a monoclonal $A b(\mathrm{mAb})$ specific against swIFN $\beta$, developed in our laboratory (10E9), was added at an optimized 
concentration, and incubated at RT for $1 \mathrm{~h}$. Plates were then washed 5 times with PBS-T and a diluted secondary antibody conjugate goat anti- mouse IgG HRPO (KPL, Gaithersburg, Maryland, USA) was added and incubated for $1 \mathrm{~h}$ at RT. Plates were washed 5 times, ABTS peroxidase substrate was added and the plate was read in an ELISA reader (Synergy HT, BioTek, Vermont, USA) at a wavelength of $405 \mathrm{~nm}$. Affinity purified swIFN $\beta$ and normal culture medium were used as a positive and negative controls for comparative purposes and to ensure the soundness of the test.

\section{Swine IFN $\beta$ bioassay}

Recombinant replication-defective adenoviruses expressing recombinant swine IFN $\beta$ (Ad5-swIFN $\beta$ ) or His-tagged Ad5swIFN $\beta$ constructed previously [37] were utilized as a source of recombinant swine IFN $\beta$ (swIFN $\beta$ ) in the study. The recombinant adenoviruses were propagated in HEK 293 cells for production of swIFN $\beta$. The swIFN $\beta$ thus produced was used in assays either as crude cell culture fluids or fractionated through affinity Sepharose-anti-swIFN $\beta$ or nickel columns.

To test the sensitivity of the SIV strains to swIFN $\beta$, SJPL cells cultured in 6-well tissue culture plates were pre-treated for 24 $h$ with varying concentrations of swIFN $\beta$. The cells were then inoculated, with each of the three SIV strains being tested, at an $\mathrm{MOI}$ of 0.005 , and incubated for $72 \mathrm{~h}$ in serum-free DMEM containing $1 \mu \mathrm{g} / \mathrm{mlTPCK}$ - trypsin. Culture fluids were collected at $0,24,48,72 \mathrm{~h}$ after infection. Virus titers were determined by plaque assays as described elsewhere.

\section{Testing effects of NS1-antagonistic compounds}

The effects of two NS1 antagonistic compounds, NSC10934 AND NSC128I164 kindly provided by the National Cancer Institute, on IFN $\beta$ induction and virus replication were tested in vitro essentially as described previously [38]. A working concentration of the compounds was determined experimentally based on this report [38]. Culture fluids were collected 72 hours post-infection and plaque assays were performed as described above to determine the virus titers.

\section{Results}

\section{Poly I:C induces IFN $\beta$ production in SJPL cells}

Polyriboinosinic-polyribocytidylic acid (poly I:C) which was previously shown to induce IFN $\beta$ in PK-15 cells [39], was used to ascertain and validate IFN $\beta$ induction in SJPL cells. Briefly, SJPL cells were treated with poly I:C (InvivoGen, San Diego, CA, USA) at different concentrations; 10, 25, and $50 \mu \mathrm{g} / \mathrm{ml}$. Culture supernatants were collected at different time points after poly I:C stimulation and acidified to $\mathrm{pH} 2.0$ overnight. The next day, supernatants were adjusted to pH 7.2 for use in ELISA which. Showed that poly I:C treatment induced increasing synthesis of IFN $\beta$ in SJPL cells over time of stimulation (Figure 1). There were significantly higher levels of IFN $\beta$ in poly I:C stimulated cells at the lowest dose $(10 \mu \mathrm{g} / \mathrm{ml})$ compared to unstimulated control cells $(p<0.05)$. Nevertheless, increasing the dose of

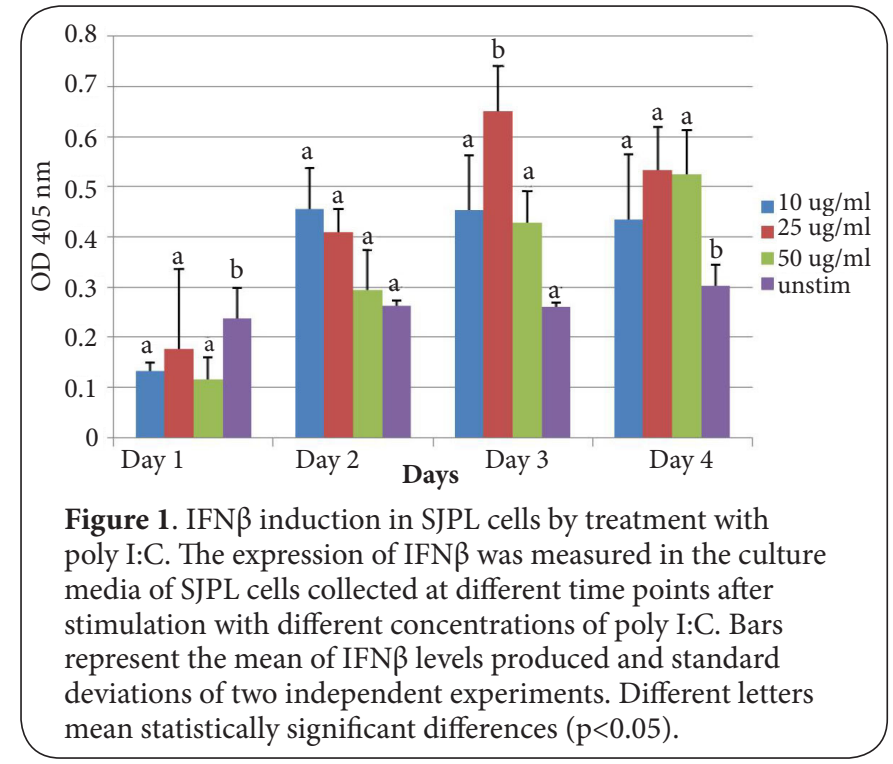

poly I: $C$ did not increase the amount of IFN $\beta$ induced. The demonstration that poly I:C treatment induced expression of IFN $\beta$ in SJPL cells, was an important step to select these cells for testing IFN $\beta$ induction and sensitivity with influenza viruses. Poly I:C-stimulated SJPL cells were utilized as a positive IFN $\beta$ inducible control in the study.

The three SIV strains tested induce IFN $\beta$ in SJPL cells The induction of IFN $\beta$ by poly I:C in SJPL cells is important since it validated the use of these cells as a system to evaluate the activation of type I IFN pathway by respiratory viruses such as influenza virus. SIV (A/Sw/lowa/73 (H1N1), A/Sw/NC/18893/01 (rH1N1), A/Sw/Tx/4199/98(H3N2) were examined for their ability to induce IFN $\beta$ in SJPL cells. ELISA results showed that the three SIV strains tested induced the production of IFN $\beta$ by SJPL cells which indicated a cross-reactivity with the mAb $10 E 9$ used in the test which was raised against recombinant swIFN $\beta$. The levels of IFN $\beta$ induced were similar among the three strains tested (Figure 2). The levels of IFN $\beta$ detected at 72 $\mathrm{h}$ p.i. were significantly higher than those in uninfected control cells $(p<0.05)$. Strains $A / S w / l o w a / 73$ and $A / S w / N C / 18893 / 01$ induced higher levels of IFN $\beta$ than $A / S w / T x / 4199 / 98$ but the differences were not statistically significant. ELISAs were repeated several times with consistent results.

To determine the effect of virus dose on induction of IFN $\beta$, SJPL cells were infected at various MOl's with $\mathrm{A} / \mathrm{Sw} / \mathrm{lowa} / 73$ (H1N1) and infected cell supernatants were treated as previously described and assayed by indirect ELISA. The results indicate that the induction of IFN $\beta$ was not dependent on the infectious virus dose (Figure 3 ).

The SIV strains tested were insensitive to exogenous swIFN $\beta$ The IFN $\beta$ sensitivity tests showed that treatment with 100, 250 , or $500 \mathrm{U}$ of swIFN $\beta$ had no effect on virus replication as 
Pangesti et al. Virology Discovery 2014,

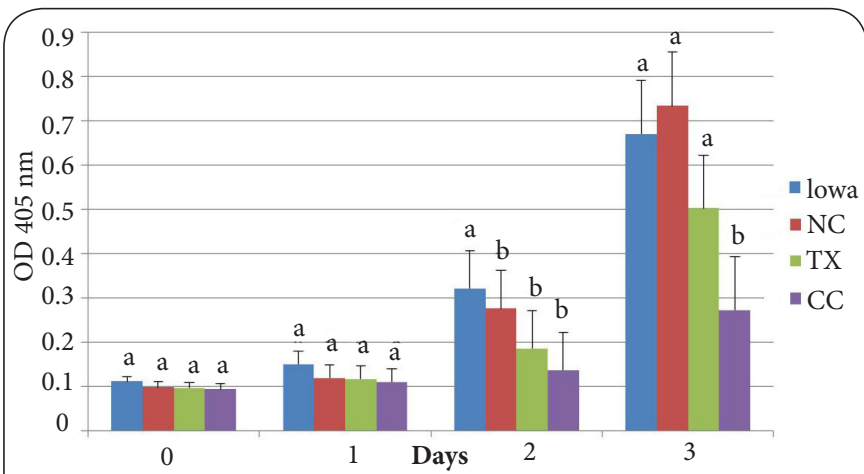

Figure 2. IFN $\beta$ induction in SJPL cells infected with different SIV strains. Expression of IFN $\beta$ was measured in culture media collected at the indicated times after infection of SJPL cells with one of three swine influenza virus strains in the presence of TPCK-trypsin. Bars represent the mean of swIFN $\beta$ levels produced and standard deviations of two independent experiments. Different letters mean statistically significant differences $(\mathrm{p}<0.05)$. cc uninfected control cells.

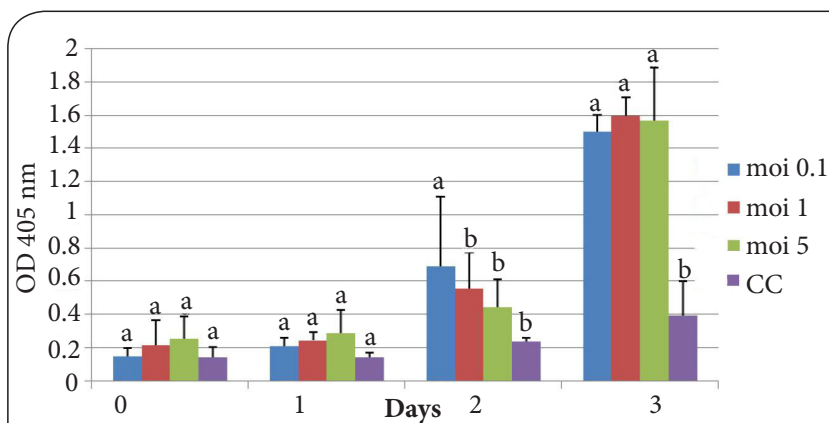

Figure 3. Induction of IFN $\beta$ in SJPL cells infected with different doses of SIV. The effect of virus dose on IFN $\beta$ expression was assessed by measuring IFN $\beta$ in the culture medium of SJPL cells after infection with $\mathrm{A} / \mathrm{sw} /$ Iowa/73. Bars represent the mean of IFN $\beta$ levels produced and standard deviations of two independent experiments. Different letters mean statistically significant differences $(p<0.05)$. cc uninfected control cells.

observed after $72 \mathrm{~h}$ of infection (data not shown). Thus, the three SIV strains tested here, A/Sw/lowa/73 (H1N1), A/Sw/ $\mathrm{NC} / 18893 / 01$ (H1N1), and A/Sw/Tx/4199/98 (H3N2), were not sensitive to exogenous swIFN $\beta$ under the conditions used as their $72 \mathrm{~h}$ titers were comparable to those of each of the corresponding viruses that were not exposed to IFN $\beta$. The lowest concentration of recombinant swIFN $\beta$ used (i.e., 100 $\mathrm{U}$ ) totally inhibited the growth of a swIFN $\beta$-sensitive porcine reproductive and respiratory syndrome virus (PRRSV) run in parallel in each bioassay. The bioassays were repeated with consistent results.

\section{Variable effects of NS1-inhibitors}

Based on preliminary runs, NS1-inhibition experiments per- formed in this study utilized at least 5 times the concentrations of inhibitor reported previously which reduced significantly the replication of three human influenza virus strains [38] and were repeated with consistent results. Neither NSC10934 nor NSC128164 had significant effects on SIV-mediated induction of IFN $\beta$ (data not shown) and these had partial or no effect on viral replication. The addition of NS1-inhibitor NSC10934 resulted in a reduction in virus titer of strain $\mathrm{A} / \mathrm{Sw} / \mathrm{lowa} / 73$ (H1N1) of over $1 \log 10$, while no visible effects on titer were detected with NSC128164 with this strain (Figure 4). In contrast, none of the two NS1 inhibitors tested here had effects on the replication of $A / S w / T x / 4199 / 98$ (H3N2) while increases in the titers of $\mathrm{A} / \mathrm{Sw} / \mathrm{NC} / 18893 / 01$ ( $\mathrm{rH} 1 \mathrm{~N} 1$ ) were detected in the presence of both compounds (Figure 4).

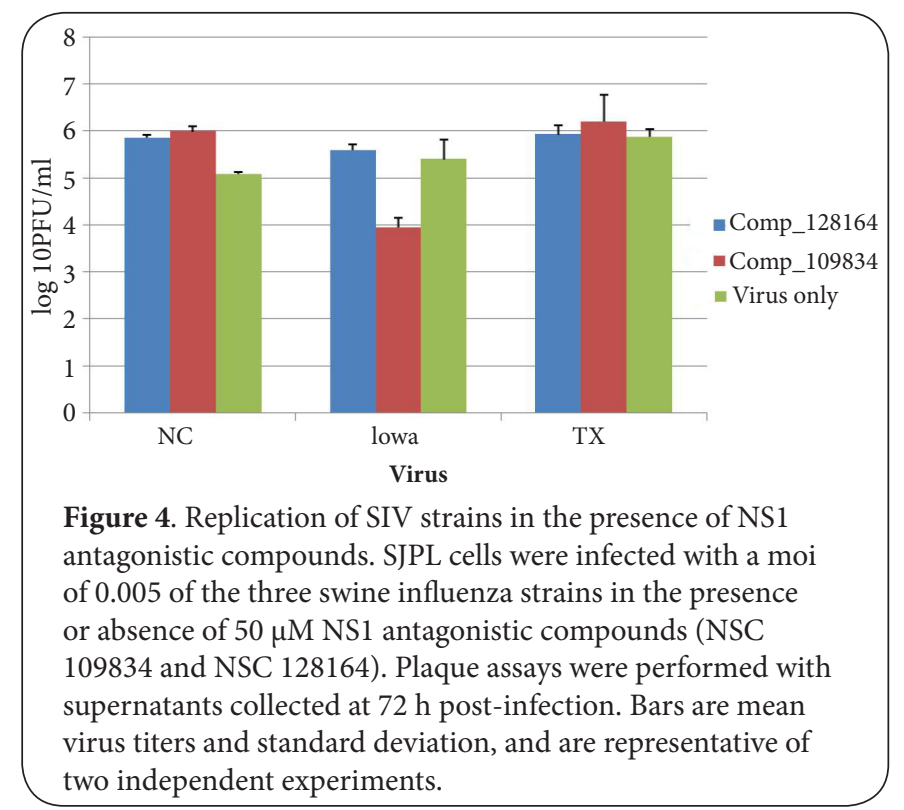

\section{Discussion}

Type I IFNs are induced within hours upon virus infection [20]. Influenza virus, as many other RNA viruses, has the ability to induce interferon both in vitro and in vivo $[24,27,28,30,34,40]$. Hayman et al., using a panel of human influenza viruses in a human alveolar cell line [A cells] demonstrated that several, but not all, human influenza viruses like A/Sydney/5/97, A/ England/41/96 both $A / H 3 N 2$ ) induced IFN $\beta$. The three strains of swine influenza in our study induced expression of IFN $\beta$ in SJPL cells and it is possible that other SIV strains exist that may be non-inducers or poor inducers of IFN $\beta$ as reported for the human influenza virus [24]. We also observed, with at least one of the strains, that the induction of IFN $\beta$ was not dependent on the infectious virus dose. Interestingly, the three study SIV strains induced IFN $\beta$ but were not susceptible to the antiviral effects of exogenous recombinant swFN $\beta$ supplied under the conditions used in these cell culture bioassays. These results are not entirely surprising as influenza viruses have 


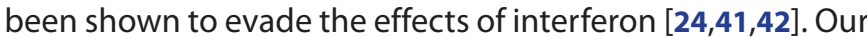
results parallel, to an extent, those reported earlier in which the strain $A / S y d n e y / 5 / 97$, an IFN $\beta$ - inducing virus, was shown to be insensitive to exogenous IFNa [24]. Also the results with SIV here appear to parallel those of a previous study in our laboratory with PRRSV, a swine arterivirus, where marked differences in sensitivity to recombinant swine IFN $\beta$ were observed in different cell types [43]. In that study, several PRRSV strains were relatively resistant to recombinant swIFN $\beta$ in MARC 145 cells, an African green monkey cell line, while proving fully sensitive in porcine alveolar macrophages. Thus, the lack of sensitivity to exogenous swIFN $\beta$ of these SIV strains in SJPL cells, may reflect lesser or absent effects of such treatment in cells of different species.

Alternatively, it could be speculated that the SIV infection induced blockage of swIFN $\beta$-mediated signaling events leading to poor antiviral state as reported earlier [46] as a potential mechanism of resistance. Correlating resistance to swIFN $\beta$ of these SIV strains as a marker of higher virulence compared to swIFN $\beta$-sensitive strains, as reported with Venezuelan equine encephalitis viruses [47] would be at best speculative at this point. Studies in animals would be required to establish whether swIFN $\beta$-inducing, swIFN $\beta$-resistant SIV strains can override the induced antiviral state, as recently reported with non-IFN inhibitory, highly pathogenic avian influenza viruses [48], and demonstrate higher pathogenicity than that of swIFN $\beta$-sensitive strains.

The NS1 protein of influenza virus has been shown to down-modulate IFNa/ $\beta$ induction as a mechanism of evasion of host response [44]. Accordingly, NS1 deletion mutants of SIV have a decreased ability to block IFNa/ $\beta$ production in vitro and are attenuated in pigs [45]. NS1 is a natural antagonist of IFNa/ $\beta$ and its effects can be inhibited by IFNa/ $\beta$ certain compounds [38]. In our study, NS1 antagonistic compounds had no significant effect on the SIV-mediated induction of IFN $\beta$ and had partial or no effect on viral replication. The later results were unexpected. When tested with or without NS1 inhibitors, the three SIV strains induced significant levels of IFN $\beta$ as compared to uninfected cells. On the other hand, the three SIV strains were resistant to exogenous IFN $\beta$ supplied in cell culture. These two biological abilities, may have masked subtle changes in IFN $\beta$ levels, if there were any in cells treated with NS1 inhibitors. The disparity of the effects of NS1 inhibitors observed on replication of the strains tested is more difficult to interpret. SJPL cells, were considered adequate for testing the effects of NS1 inhibition on SIV infection since the cells were shown to be IFN $\beta$-competent both by poly I:C induction assays as well as SIV infection. Moreover, the NS1-inhibition experiments utilized at least 5 times the concentrations of inhibitor reported previously to reduce significantly the replication of three human influenza virus strains [38]. NS1independent mechanisms of evasion from type I IFN should also be considered $[\mathbf{2 6 , 4 2 ]}$ especially for the two SIV strains that showed resistance to both inhibitors. In light of data on human or avian influenza NS1s negative effects on human IFNa/ $\beta$ expression $[\mathbf{2 4 , 4 1}$ ], closer analysis of the NS1 biology for IFN $\beta$-inducing and non-inducing strains would be necessary to better understand the results observed with the SIV strains examined here. The SJPL cells, used here without prior knowledge of host origin, proved useful to assay SIV in the context of IFN $\beta$.

\section{Conclusions}

SJPL produce IFN $\beta$ upon stimulation with poly I:C thus making them appropriate to test for IFN $\beta$ induction post viral infection. Three strains of SIV tested here, were shown to induce significant synthesis of IFN $\beta$ in SJPL cells. However, it was also shown that exogenous recombinant swine IFN $\beta$ had no significant inhibitory effect on the replication of these SIV strains. Moreover, NS1-antagonistic compounds did not affect IFN $\beta$ induction and had variable and unexpected effects on replication of the SIV strains tested. These seemingly contradicting results suggest virus evasion by mechanisms other than NS1.

\section{Competing interests}

The authors declare that they have no competing interests.

Authors' contributions

\begin{tabular}{|l|c|c|c|}
\hline Authors' contributions & KNAP & MJG & AEG \\
\hline Research concept and design & $\checkmark$ & $\checkmark$ & $\checkmark$ \\
\hline Collection and/or assembly of data & $\checkmark$ & -- & -- \\
\hline Data analysis and interpretation & $\checkmark$ & $\checkmark$ & $\checkmark$ \\
\hline Writing the article & $\checkmark$ & -- & $\checkmark$ \\
\hline Critical revision of the article & $\checkmark$ & $\checkmark$ & $\checkmark$ \\
\hline Final approval of article & $\checkmark$ & $\checkmark$ & $\checkmark$ \\
\hline Statistical analysis & $\checkmark$ & -- & -- \\
\hline
\end{tabular}

Acknowledgement and funding

This study was funded by the HICD-USAID Program. The authors thank the National Cancer Institute for providing NS1-inhibitory compounds, Dr. Richard Mancini for support in statistical analysis and Dr. Surya Waghela for review and suggestions on the manuscript. The authors also thank Drs. Rajnikanth Maganti, Sankhiros Babapoor, and Christopher Overend, and Mrs. Sreedevi Bodepudi for valuable comments and assistance during the study.

Publication history

Editor: Upal Roy, Florida International University, USA.

EIC: Preet M. Chaudhary, University of Southern California, Keck School of Medicine, USA.

Received: 29-Apr-2014 Final Revised: 28-Sep-2014

Accepted: 21-Oct-2014 Published: 28-Oct-2014

\section{References}

1. Olsen CW, Brown IH, Easterday BC and Van Reeth K. Swine Influenza. In Diseases of Swine (9th edition). Edited by Straw BE, Zimmerman JJ, D'Allaire S, Taylor DJ. lowa. Blackwell Publishing. 2006; 469-483.

2. B.S. Kamps and Teran GR. Influenza 2006. In Influenza Report 2006 (1st edition). Kamps BS, Hoffman C, Preiser W, eds. Cologne: Flying Publisher. 
Pangesti et al. Virology Discovery 2014,

http://www.hoajonline.com/journals/pdf/2052-6202-2-3.pdf

doi: $10.7243 / 2052-6202-2-3$

2006; 17-38. I Book

3. Horimoto T and Kawaoka Y. Influenza: lessons from past pandemics, warnings from current incidents. Nat Rev Microbiol. 2005; 3:591-600. | Article I PubMed

4. Gatherer D. The 2009 H1N1 influenza outbreak in its historical context. J Clin Virol. 2009; 45:174-8. | Article | PubMed

5. J.S.M. Peiris JSM, Poon LLM and Guan Y. Emergence of novel swine-origin influenza A virus (S-OIV) H1N1 virus in humans. J.Clinical Virol. 2009; 45:169-173. | Article

6. Gao R, Cao B, Hu Y, Feng Z, Wang D, Hu W, Chen J, Jie Z, Qiu H, Xu K and $\mathrm{Xu} X$ et al. Human infection with a novel avian-origin influenza $A$ (H7N9) virus. N Engl J Med. 2013; 368:1888-97. I Article I PubMed

7. Zhou NN, Senne DA, Landgraf JS, Swenson SL, Erickson G, Rossow K, Liu L, Yoon K, Krauss S and Webster RG. Genetic reassortment of avian, swine, and human influenza A viruses in American pigs. J Virol. 1999; 73:88516. | Article | PubMed Abstract | PubMed Full Text

8. Ma W, Kahn RE and Richt JA. The pig as a mixing vessel for influenza viruses: Human and veterinary implications. J Mol Genet Med. 2008; 3:158-66. | Article | PubMed Abstract | PubMed Full Text

9. Thacker $E$ and Janke $B$. Swine influenza virus: zoonotic potential and vaccination strategies for the control of avian and swine influenzas. $J$ Infect Dis. 2008; 197 Suppl 1:S19-24. | Article | PubMed

10. Ito T, Couceiro JN, Kelm S, Baum LG, Krauss S, Castrucci MR, Donatelli I, Kida H, Paulson JC, Webster RG and Kawaoka Y. Molecular basis for the generation in pigs of influenza A viruses with pandemic potential. J Virol. 1998; 72:7367-73. I Article I PubMed Abstract I PubMed Full Text

11. Karasin Al, Carman S and Olsen CW. Identification of human H1N2 and human-swine reassortant $\mathrm{H} 1 \mathrm{~N} 2$ and $\mathrm{H} 1 \mathrm{~N} 1$ influenza $A$ viruses among pigs in Ontario, Canada (2003 to 2005). J Clin Microbiol. 2006; 44:11236. | Article | PubMed Abstract | PubMed Full Text

12. Yu H, Zhou YJ, Li GX, Zhang GH, Liu HL, Yan LP, Liao M and Tong GZ. Further evidence for infection of pigs with human-like H1N1 influenza viruses in China. Virus Res. 2009; 140:85-90. I Article I PubMed

13. Richt JA, Lager KM, Janke BH, Woods RD, Webster RG and Webby RJ. Pathogenic and antigenic properties of phylogenetically distinct reassortant H3N2 swine influenza viruses cocirculating in the United States. J Clin Microbiol. 2003; 41:3198-205. | Article | PubMed Abstract | PubMed Full Text

14. Brown IH. The epidemiology and evolution of influenza viruses in pigs. Vet Microbiol. 2000; 74:29-46. | Article | PubMed

15. Van Reeth K. Avian and swine influenza viruses: our current understanding of the zoonotic risk. Vet Res. 2007; 38:243-60. | Article I PubMed

16. Haller $\mathrm{O}$, Kochs $\mathrm{G}$ and Weber $\mathrm{F}$. Interferon, $\mathbf{M x}$, and viral countermeasures. Cytokine Growth Factor Rev. 2007; 18:425-33. I Article I PubMed

17. Katze MG, He Y and Gale M, Jr. Viruses and interferon: a fight for supremacy. Nat Rev Immunol. 2002; 2:675-87. I Article I PubMed

18. Hallum JV, Thacore HR and Youngner JS. Factors affecting the sensitivity of different viruses to interferon. J Virol. 1970; 6:156-62. | Article | PubMed Abstract | PubMed Full Text

19. P.I. Marcus, Rojek JM and Sekellick MJ. Interferon induction and/or production and lits suppression by influenza A viruses. J. Virol. 2005; 79:2880-2890. | Article

20. D.E. Levy and Marie I.J. How viruses elicit interferon production: Triggering the innate immune response to viral infection. In Modulation of Host Gene Expression and Innate Immunity by Viruses. Ed Peter Palese. Springer. The Netherlands. 2005. | Article

21. Garcia-Sastre A and Biron CA. Type 1 interferons and the virus-host relationship: a lesson in detente. Science. 2006; 312:879-82. | Article | PubMed

22. Ito $Y$ and Montagnier L. Heterogeneity of the sensitivity of vesicular stomatitis virus to interferons. Infect Immun. 1977; 18:23-7. I Article I PubMed Abstract | PubMed Full Text

23. S.E. Grossberg. Interferons: An overview of their biological and biochemical properties. In mechanisms of interferon actions. Volume I. ed. Pfeffer, L.M.,CRC 403 Press.Florida. 1987; 1-26.
24. Hayman A, Comely S, Lackenby A, Murphy S, McCauley J, Goodbourn S and Barclay W. Variation in the ability of human influenza $A$ viruses to induce and inhibit the IFN-beta pathway. Virology. 2006; 347:52-64. I Article | PubMed

25. Phipps-Yonas H, Seto J, Sealfon SC, Moran TM and Fernandez-Sesma A. Interferon-beta pretreatment of conventional and plasmacytoid human dendritic cells enhances their activation by influenza virus. PLOS Pathog. 2008; 4:e1000193. | Article | PubMed Abstract | PubMed Full Text

26. Pauli EK, Schmolke M, Wolff T, Viemann D, Roth J, Bode JG and Ludwig S. Influenza A virus inhibits type I IFN signaling via NF-kappaB-dependent induction of SOCS-3 expression. PLoS Pathog. 2008; 4:e1000196. | Article I PubMed Abstract I PubMed Full Text

27. Summerfield A, Guzylack-Piriou L, Schaub A, Carrasco CP, Tache V, Charley $B$ and McCullough KC. Porcine peripheral blood dendritic cells and natural interferon-producing cells. Immunology. 2003; 110:440-9. Article | PubMed Abstract | PubMed Full Text

28. Barbe F, Atanasova $\mathrm{K}$ and Van Reeth $\mathrm{K}$. Cytokines and acute phase proteins associated with acute swine influenza infection in pigs. Vet J. 2011; 187:48-53. | Article | PubMed

29. Summerfield A. Viewpoint: factors involved in type I interferon responses during porcine virus infections. Vet Immunol Immunopathol. 2012; 148:168-71. | Article | PubMed

30. Jung $\mathrm{K}$ and $\mathrm{Chae} \mathrm{C}$. Expression of $\mathrm{Mx}$ protein and interferon-alpha in pigs experimentally infected with swine influenza virus. Vet Pathol. 2006; 43:161-7. | Article | PubMed

31. Nakajima E, Morozumi T, Tsukamoto K, Watanabe T, Plastow G and Mitsuhashi T. A naturally occurring variant of porcine Mx1 associated with increased susceptibility to influenza virus in vitro. Biochem Genet. 2007; 45:11-24. I Article I PubMed

32. Palm M, Garigliany MM, Cornet F and Desmecht D. Interferon-induced Sus scrofa Mx1 blocks endocytic traffic of incoming influenza A virus particles. Vet Res. 2010; 41:29. | Article | PubMed Abstract | PubMed Full Text

33. Van Reeth K, Van Gucht S and Pensaert M. Correlations between lung proinflammatory cytokine levels, virus replication, and disease after swine influenza virus challenge of vaccination-immune pigs. Viral Immunol. 2002; 15:583-94. | Article I PubMed

34. Wesley RD, Lager KM and Kehrli ME, Jr. Infection with Porcine reproductive and respiratory syndrome virus stimulates an early gamma interferon response in the serum of pigs. Can J Vet Res. 2006; 70:176-82. | PubMed Abstract | PubMed Full Text

35. Barbe F, Saelens X, Braeckmans D, Lefevre F and Reeth KV. Role of IFNalpha during the acute stage of a swine influenza virus infection. Res Vet Sci. 2010; 88:172-8. | Article | PubMed

36. Silversides DW, Music N, Jacques M, Gagnon CA and Webby R. Investigation of the species origin of the St. Jude Porcine Lung epithelial cell line (SJPL) made available to researchers. J Virol. 2010; 84:5454-5. | Article | PubMed Abstract | PubMed Full Text

37. Chinsangaram J, Koster M and Grubman MJ. Inhibition of L-deleted footand-mouth disease virus replication by alpha/beta interferon involves double-stranded RNA-dependent protein kinase. J Virol. 2001; 75:5498503. | Article | PubMed Abstract | PubMed Full Text

38. Basu D, Walkiewicz MP, Frieman M, Baric RS, Auble DT and Engel DA. Novel influenza virus NS1 antagonists block replication and restore innate immune function. J Virol. 2009; 83:1881-91. | Article | PubMed Abstract | PubMed Full Text

39. M. Amadori, Bugnetti M and Tironi D. Induction and characterization of swine $\beta$ interferon. Comparative Immunology, Microbiology and Infectious Disease. 1987; 10:71-78. | Article

40. E. De Maeyer and De Maeyer G.J. Interferons and regulatory cytokines. John Willey and Sons. 1988.

41. Hayman A, Comely S, Lackenby A, Hartgroves LC, Goodbourn S, McCauley JW and Barclay WS. NS1 proteins of avian influenza $A$ viruses can act as antagonists of the human alpha/beta interferon response. $J$ Virol. 2007; 81:2318-27. | Article | PubMed Abstract | PubMed Full Text

42. Wolff T and Ludwig S. Influenza viruses control the vertebrate type I 
interferon system: factors, mechanisms, and consequences. J Interferon Cytokine Res. 2009; 29:549-57. | Article | PubMed

43. He D, Overend C, Ambrogio J, Maganti RJ, Grubman MJ and Garmendia AE. Marked differences between MARC-145 cells and swine alveolar macrophages in IFNbeta-induced activation of antiviral state against PRRSV. Vet Immunol Immunopathol. 2011; 139:57-60. | Article | PubMed

44. Garcia-Sastre A, Egorov A, Matassov D, Brandt S, Levy DE, Durbin JE, Palese $P$ and Muster T. Influenza $A$ virus lacking the NS1 gene replicates in interferon-deficient systems. Virology. 1998; 252:324-30. | Article | PubMed

45. Solorzano A, Webby RJ, Lager KM, Janke BH, Garcia-Sastre A and Richt JA. Mutations in the NS1 protein of swine influenza virus impair anti-interferon activity and confer attenuation in pigs. J Virol. 2005; 79:7535-43. I Article | PubMed Abstract | PubMed Full Text

46. Jia D, Rahbar R, Chan RW, Lee SM, Chan MC, Wang BX, Baker DP, Sun B, Peiris JS, Nicholls JM and Fish EN. Influenza virus non-structural protein 1 (NS1) disrupts interferon signaling. PLoS One. 2010; 5:e13927. | Article | PubMed Abstract | PubMed Full Text

47. Spotts DR, Reich RM, Kalkhan MA, Kinney RM and Roehrig JT. Resistance to alpha/beta interferons correlates with the epizootic and virulence potential of Venezuelan equine encephalitis viruses and is determined by the $5^{\prime}$ noncoding region and glycoproteins. J Virol. 1998; 72:1028691. | Article | PubMed Abstract | PubMed Full Text

48. Penski N, Hartle S, Rubbenstroth D, Krohmann C, Ruggli N, Schusser B, Pfann M, Reuter A, Gohrbandt S, Hundt J, Veits J, Breithaupt A, Kochs G, Stech J, Summerfield A, Vahlenkamp T, Kaspers B and Staeheli P. Highly pathogenic avian influenza viruses do not inhibit interferon synthesis in infected chickens but can override the interferon-induced antiviral state. J Virol. 2011; 85:7730-41. | Article | PubMed Abstract | PubMed Full Text

\section{Citation:}

Pangesti KNA, Grubman MJ and Garmendia AE. Swine influenza virus strains that induce interferon $\beta$ in SJPL cells but are insensitive to exogenous recombinant swine interferon 及. Virol Discov. 2014; 2:3. http://dx.doi.org/10.7243/2052-6202-2-3 